\title{
THE VITAL IMPORTANCE OF PROVIDING SOUND SCIENTIFIC ADVICE TO POLICY MAKERS IN GOVERNMENT
}

\author{
Graham S. PEARSON \\ Visiting Professor of International Security \\ Division of Peace Studies \\ University of Bradford; \\ Bradford, West Yorkshire BD7 1DP, United Kingdom
}

1. The Biological and Toxin Weapons Convention (BTWC) was opened for signature on 10 April 1972 and entered into force on 26 March 1975. The Co-Depositaries for this Convention are the Russian Federation, the United Kingdom and the United States. This Convention was the first one to totally prohibit the development, production and stockpiling of a class of weapons of mass destruction - that involving the use of biological agents and toxins as weapons. Ukraine was one of the original States Parties who signed the Convention on 10 April 1972 and for whom the Convention entered into force on 26 March 1975. The central prohibition is set out in Article I of the Convention [1] under which:

Each State Party to this Convention undertakes never in any circumstances to develop, produce, stockpile or otherwise acquire or retain:

(1) Microbial or other biological agents, or toxins whatever their origin or method of production, of types and quantities that have no justification for prophylactic, protective or other peaceful purposes;

(2) Weapons, equipment or means of delivery designed to use such agents or toxins for hostile purposes or in armed conflict.

2. In accordance with Article XII of the Convention, Review Conferences have been held at five year intervals - in 1981, 1986, 1991, 1996, 2001/2, 2006 and 2011 - to review the operation of the Convention, with a view to ensuring that the purposes of the preamble of the Convention, ... are being realized. In addition, it is required that Such review shall take into account any new scientific and technological developments relevant to the Convention. It is thus evident that the continuing and effective implementation of the Convention requires that the
States Parties carrying out the five yearly Review Conferences need to be advised of any relevant new scientific and technological developments and of what their significance is for the Convention and what should be done in order to ensure that the effectiveness of the Convention is maintained.

3. The need to be able to provide sound scientific advice to policy makers and diplomats in government in each State Party is thus enshrined in the BTWC. And, it is also evident that the delegations sent by States Parties to the Review Conferences will need to include qualified and knowledgeable scientists who will be able to provide advice to the delegations during the Review Conferences on approaches to be adopted by the delegation as well as how to respond to scientific and technical information submitted and recommendations made by other delegations.

4. Although Review Conferences take place at five year intervals, the practice has been adopted since the decision of the Fifth Review Conference in 2002, to have an intersessional programme during which the States Parties are each year to discuss and promote common understandings and effective action on specified topics first at an annual Meeting of Experts and then subsequently at an annual Meeting of States Parties. As might be expected, the delegations sent to the Meeting of Experts need to include qualified and knowledgeable scientists who will be able to provide advice to the delegations during the Meeting of Experts at which scientific and technical details are discussed and debated in regard to the specific items so as to ensure that the ideas captured in the Annex to the Meeting of Experts are correctly expressed and can lead to being agreed in the substantive paragraphs of the subsequent Meeting of States Parties later that year that will be considering the same specific topics.

\footnotetext{
$\uparrow$ Previously the Director-General of the Chemical and Biological Defence Establishment, Porton Down, UK from 1984 to 1995 .
} 


\section{QUALIFIED AND KNOWLEDGEABLE SCIENTISTS}

5. For scientists to be effective in providing advice to the policy makers and the diplomats, there are several essential characteristics that the scientist is required to have.

\section{Awareness and understanding of the BTWC}

6. An essential prerequisite for any scientist providing advice to policy makers and diplomats on the BTWC is an understanding of the Convention and an appreciation of what the various Articles of the Convention oblige States Parties to do. In addition, the scientist needs to be aware of the extended understandings that have been agreed by the States Parties at the successive Review Conferences. This overall awareness and understanding is essential if the advice is going to be credible and helpful to the policy makers and diplomats.

7. In addition, the advice will be much more effective if the scientist is also aware of what the last Review Conference has decided - the Final Report of the Review Conference and, in particular, its Final Declaration and its Decisions and Recommendations set the scene for the current Intersessional Period and have decided the specific topics to be discussed in order to promote common understandings and effective action.

Ability to analyse, summarise and express relevant scientific aspects

8. Another essential prerequisite is that the scientist providing scientific advice is able to analyse and summarise the relevant scientific aspects of the particular topic on which advice is to be given to the policy makers and diplomats. Such analysis has to be able to identify the key elements that are relevant and these need to be expressed so that the implications in regard to the various elements of the Convention are clearly appreciated and understood by the policy makers and diplomats. In other words, the relevant scientific aspects have to be analysed, summarized and presented in the context of the Convention together with proposals as to what steps should be taken by the policy makers and diplomats. Throughout, the scientist has to be answering the question that the policy makers and diplomats will be asking themselves about the scientific aspects - "So what?" In other words, what do the scientific aspects mean in the context of the Convention.

\section{Awareness of the risks to humans,} animals and plants

9. One of the extended understandings that the States Parties have agreed at the successive Review Conferences is encapsulated in the language relating to Article I of the Convention in the Final Declaration [2] of the Seventh Review Conference that states:

\section{The Conference reaffirms the importance of Article I, as it defines the scope of the Conven- tion. The Conference declares that the Conven- tion is comprehensive in its scope and that all naturally or artificially created or altered mi- crobial and other biological agents and toxins, as well as their components, regardless of their origin and method of production and whether they affect humans, animals or plants, of types and in quantities that have no justification for prophylactic, protective or other peaceful pur- poses, are unequivocally covered by Article I. [Emphasis added]}

This makes it clear that the prohibition in the Convention applies to microbial and other biological agents and toxins that affect humans, animals or plants. It consequently follows that the scientists providing policy advice on the BTWC to the policy makers and diplomats need to be aware of the activities being carried out by the World Health Organization (WHO) [3], the World Animal Health Organization (OIE) [4] and the Food and Agriculture Organization (FAO) [5] in regard to countering outbreaks of human, animal and plant diseases and to promote human health security, animal health security and food security.

10. These scientists providing policy advice need also to be aware that the terminology used in regard to terms such as biosafety, biosecurity and food security can be different in the WHO, OIE and FAO arenas than that used in the context of the Convention.

\section{Awareness of the risks to the environment}

11. As the prohibition in the Convention relates to microbial and other biological agents and toxins that affect humans, animals or plants, it will be appreciated that there is a close relationship to the environment. Consequently, the scientists providing advice need also to be aware of the Conventions and Protocols that relate to the environment - and in particular to the Convention on 
Biological Diversity and its associated Cartagena Protocol on Biosafety.

The Convention on Biological Diversity (CBD) [6] was the result of an increasing global awareness that:

The Earth's biological resources are vital to humanity's economic and social development. As a result, there is a growing recognition that biological diversity is a global asset of tremendous value to present and future generations. At the same time, the threat to species and ecosystems has never been so great as it is today. Species extinction caused by human activities continues at an alarming rate.

The CBD was opened for signature on 5 June 1992 at the United Nations Conference on Environment and Development (the Rio "Earth Summit") and entered into force on 29 December 1993. It has currently 193 Parties to the Convention.

12. A particular element of the CBD arises from Article 18 Technical and Scientific Cooperation which requires that:

1. The Contracting Parties shall promote international technical and scientific cooperation in the field of conservation and sustainable use of biological diversity, where necessary, through the appropriate international and national institutions.

2. Each Contracting Party shall promote technical and scientific cooperation with other Contracting Parties, in particular developing countries, in implementing this Convention, inter alia, through the development and implementation of national policies. In promoting such cooperation, special attention should be given to the development and strengthening of national capabilities, by means of human resources development and institution building.

3. The Conference of the Parties, at its first meeting, shall determine how to establish a clearing-house mechanism to promote and facilitate technical and scientific cooperation.

The clearing-house mechanism addressed in paragraph 3 of Article 18 has as its mission the requirement to contribute significantly to the implementation of the Convention on Biological Diversity through effective information services and other appropriate means in order to promote and facilitate scientific and technical cooperation, knowledge sharing and information exchange, and to establish a fully operational network of Parties and partners.
13. Closely associated with the CBD is its Cartagena Protocol on Biosafety [7]. This addresses the movements of living modified organisms (LMOs) resulting from modern biotechnology from one country to another. It was adopted on 29 January 2000 as a supplementary agreement to the Convention on Biological Diversity and entered into force on 11 September 2003. It establishes an advance informed agreement (AIA) procedure for ensuring that countries are provided with the information necessary to make informed decisions before agreeing to the import of such organisms into their territory. The Protocol contains reference to a precautionary approach. The Protocol also establishes a Biosafety ClearingHouse to facilitate the exchange of information on living modified organisms and to assist countries in the implementation of the Protocol. It has currently 166 Parties to the Protocol. The Ukraine Profile is available at http://bch.cbd.int/about/ countryprofile.shtml? country $=$ ua.

14. Article 22 of the Protocol addresses $\mathrm{Ca}$ pacity Building and requires that:

1. The Parties shall cooperate in the development and/or strengthening of human resources and institutional capacities in biosafety, including biotechnology to the extent that it is required for biosafety, for the purpose of the effective implementation of this Protocol, in developing country Parties, in particular the least developed and small island developing States among them, and in Parties with economies in transition, including through existing global, regional, subregional and national institutions and organizations and, as appropriate, through facilitating private sector involvement.

2. For the purposes of implementing paragraph 1 above, in relation to cooperation, the needs of developing country Parties, in particular the least developed and small island developing States among them, for financial resources and access to and transfer of technology and knowhow in accordance with the relevant provisions of the Convention, shall be taken fully into account for capacity-building in biosafety. Cooperation in capacity-building shall, subject to the different situation, capabilities and requirements of each Party, include scientific and technical training in the proper and safe management of biotechnology, and in the use of risk assessment and risk management for biosafety, and the enhancement of technological and institutional capacities in biosafety. The needs of Parties with economies in transition shall also be taken fully into account for such capacity-building in biosafety. 
15. Closely related to the biosafety requirements for the Protocol is the initiative taken by the United Nations Environment Programme to implement the Global Environment Facility (GEF) Initial Strategy on Biosafety [8] which was adopted in November 2000. This Strategy aims to assist countries preparing for the Cartagena Biosafety Protocol through the establishment of National Biosafety Frameworks (NBFs). The NBF is a combination of policy, legal, administrative and technical instruments that are set in place to address safety for the environment and human health in relation to modern biotechnology. As at 30th May 2012, 119 countries have completed the majority of development of their National Biosafety Projects and their draft NBFs are available online [9]. This includes the draft National Biosafety Framework for the Ukraine. These projects have generated a wealth of in-country experience in building capacity for biosafety.

16. These National Biosafety Frameworks are highly relevant to the initiatives being taken to strengthen biosafety and biosecurity under the BTWC and scientific experts advising national diplomats and policy makers need to be aware of their relevance.

17. There are also, as might be expected, relevant activities in regard to education and awareness. Thus the Convention on Biological Diversity in its Article 13 Public Education and Awareness requires that:

\section{The Contracting Parties shall:}

(a) Promote and encourage understanding of the importance of, and the measures required for, the conservation of biological diversity, as well as its propagation through media, and the inclusion of these topics in educational programmes; and

(b) Cooperate, as appropriate, with other States and international organizations in developing educational and public awareness programmes, with respect to conservation and sustainable use of biological diversity.

Likewise the Cartagena Protocol on Biosafety in its Article 23 Public Awareness and Education requires that:

\section{The Parties shall:}

(a) Promote and facilitate public awareness, education and participation concerning the safe transfer, handling and use of living modified organisms in relation to the conservation and sustainable use of biological diversity, taking also into account risks to human health. In doing so, the Parties shall cooperate, as appropriate, with other States and international bodies;

(b) Endeavour to ensure that public awareness and education encompass access to information on living modified organisms identified in accordance with this Protocol that may be imported.

There are consequently clear benefits to States Parties to the BTWC if those scientists providing advice to diplomats and policy makers are aware of the international and national activities associated with the Convention on Biological Diversity and its Cartagena Protocol on Biosafety.

\section{Awareness of CBRN risks and preparedness}

18. Whilst it may be thought that scientists providing advice to diplomats and policy makers need only be aware of the life sciences, their advice will be much more effective if they are also aware of the broader chemical, biological, radiological and nuclear risks as to an increasing extent countries are coordinating their preparedness for CBRN incidents whether accidental or deliberate.

19. The Chemical Weapons Convention. The CWC [10] is closely related to the BTWC and it prohibits the development, production and stockpiling of chemical weapons. In Article I General Obligations it requires that:

1. Each State Party to this Convention undertakes never under any circumstances:

(a) To develop, produce, otherwise acquire, stockpile or retain chemical weapons, or transfer, directly or indirectly, chemical weapons to anyone;

(b) To use chemical weapons;

(c) To engage in any military preparations to use chemical weapons;

(d) To assist, encourage or induce, in any way, anyone to engage in any activity prohibited to a State Party under this Convention.

and in its Article II Definitions and Criteria states that:

For the purposes of this Convention:

1. "Chemical Weapons" means the following, together or separately:

(a) Toxic chemicals and their precursors, except where intended for purposes not prohibited under this Convention, as long as the types and quantities are consistent with such purposes;

(b) Munitions and devices, specifically designed to cause death or other harm through the toxic properties of those toxic chemicals specified in 
subparagraph (a), which would be released as a result of the employment of such munitions and devices;

(c) Any equipment specifically designed for use directly in connection with the employment of munitions and devices specified in subparagraph (b).

\section{2. "Toxic Chemical" means:}

Any chemical which through its chemical action on life processes can cause death, temporary incapacitation or permanent harm to humans or animals. This includes all such chemicals, regardless of their origin or of their method of production, and regardless of whether they are produced in facilities, in munitions or elsewhere.

As the BTWC addresses Microbial or other biological agents, or toxins whatever their origin or method of production it is evident that there is and rightly so - an overlap between the two Conventions with chemicals such as toxins being prohibited under both Conventions.

20. The Chemical Weapons Convention opened for signature on 13 January 1993 and entered into force on 29 April 1997. It currently has 188 States Parties. The CWC has concentrated in its first fifteen years on the destruction of declared chemical weapons stockpiles - the Convention in Article IV requires that Each State Party shall destroy all chemical weapons ... Such destruction ... shall finish no later than 10 years after entry into force of the Convention. In addition, Part IV(A) of the Verification Annex to the Convention includes provisions should a State Party believe that it will be unable to ensure the destruction of all Category 1 chemical weapons not later than 10 years after the entry into force of this Convention then the Executive Council can grant an extension - however, it is specified that Any extension shall be the minimum necessary, but in no case shall the deadline for a State Party to complete its destruction of all chemical weapons be extended beyond 15 years after the entry into force of this Convention. The Convention is now focusing much more on the non-proliferation and other requirements required by the Convention and the activities of the Organisation for the Prohibition of Chemical Weapons are more closely related to those being carried out by the States Parties to the BTWC.

21. The 1925 Geneva Protocol. This is the Protocol for the Prohibition of the Use in War of Asphyxiating, Poisonous or other Gases, and of Bacteriological Methods of Warfare [11] which was signed at Geneva on 17 June 1925. This notes that:
Whereas the use in war of asphyxiating, poisonous or other gases, and of all analogous liquids, materials or devices, has been justly condemned by the general opinion of the civilised world; and

Whereas the prohibition of such use has been declared in Treaties to which the majority of Powers of the world are Parties; and

To the end that this prohibition shall be universally accepted as a part of International Law, binding alike the conscience and the practice of nations;

and goes on to declare that:

\section{Declare:}

That the High Contracting Parties, so far as they are not already Parties to Treaties prohibiting such use, accept this prohibition, agree to extend this prohibition to the use of bacteriological methods of warfare and agree to be bound as between themselves according to the terms of this declaration.

The High Contracting Parties will exert every effort to induce other States to accede to the present Protocol. Such accession will be notified to the Government of the French Republic, and by the latter to all signatory and acceding Powers, and will take effect on the date of the notification by the Government of the French Republic.

22. It should be noted that at the Seventh Review Conference of the BTWC, the States Parties agreed in their Final Declaration [12] in regard to Article VIII of the BTWC that:

41. The Conference appeals to all States Parties to the 1925 Geneva Protocol to fulfil their obligations assumed under that Protocol and urges all states not yet party to the Protocol to ratify or accede to it without further delay.

42. The Conference acknowledges that the 1925 Geneva Protocol, which prohibits the use in war of asphyxiating, poisonous or other gases, and of bacteriological methods of warfare, and the Convention complement each other. The Conference reaffirms that nothing contained in the Convention shall be interpreted as in any way limiting or detracting from the obligations assumed by any state under the 1925 Geneva Protocol.

43. The Conference stresses the importance of the withdrawal of all reservations to the 1925 Geneva Protocol related to the Convention. 
44. The Conference recalls the actions which States Parties have taken to withdraw their reservations to the 1925 Geneva Protocol related to the Convention, and calls upon those States Parties that continue to maintain pertinent reservations to the 1925 Geneva Protocol to withdraw those reservations, and to notify the Depositary of the 1925 Geneva Protocol accordingly, without delay.

45. The Conference notes that reservations concerning retaliation, through the use of any of the objects prohibited by the Convention, even conditional, are totally incompatible with the absolute and universal prohibition of the development, production, stockpiling, acquisition and retention of bacteriological (biological) and toxin weapons, with the aim to exclude completely and forever the possibility of their use.

46. The Conference notes that the SecretaryGeneral's investigation mechanism, set out in A/44/561 and endorsed by the General Assembly in its resolution 45/57, represents an international institutional mechanism for investigating cases of alleged use of biological or toxin weapons. The Conference notes national initiatives to provide relevant training to experts that could support the Secretary-General's investigative mechanism.

23. Universal adherence to the Geneva Protocol by all States, including all States Parties to the BTWC, has been an agreed politically binding commitment since 1980, reaffirmed by every subsequent Review Conference that has issued a Final Declaration. It should be noted that the original statement, in the Final Declaration which the First Review Conference agreed on 21 March 1980, called on all States not yet parties to the Geneva Protocol to ratify or accede to it at the earliest possible date; the Second Review Conference on 26 September 1986 urged them to adhere to it at the earliest possible date; the Third Review Conference on 27 September 1991 urged them to accede to it without delay, as did the Fourth Review Conference on 6 December 1996, the Sixth Review Conference on 8 December 2006 and the Seventh Review Conference on 22 December 2011.

24. Secretary-General Mechanism for Investigation of Alleged Use [13]. Article VI of the BTWC states that:

(1) Any State Party to this Convention which finds that any other State Party is acting in breach of obligations deriving from the provisions of the Convention may lodge a complaint with the Security Council of the United $\mathrm{Na}$ - tions. Such a complaint should include all possible evidence confirming its validity, as well as a request for its consideration by the Security Council.

(2) Each State Party to this Convention undertakes to cooperate in carrying out any investigation which the Security Council may initiate, in accordance with the provisions of the Charter of the United Nations, on the basis of the complaint received by the Council. The Security Council shall inform the States Parties to the Convention of the results of the investigation.

25. At the Seventh Review Conference, the States Parties to the BTWC agreed in their Final Declaration [14] in regard to Article VI that:

29. The Conference invites the Security Council:

(a) to consider immediately any complaint lodged under this Article and to initiate any measures it considers necessary for the investigation of the complaint in accordance with the Charter;

(b) to request, if it deems necessary and in accordance with its Resolution 620 of 1988, the United Nations Secretary-General to investigate the allegation of use, using the technical guidelines and procedures contained in Annex I of United Nations Document A/44/561;

(c) to inform each State Party of the results of any investigation initiated under this Article and to consider promptly any appropriate further action which may be necessary.

26. The Secretary-General's Mechanism (SGM) for the investigation of alleged use of chemical, biological and toxin weapons derives from a mandate established by the United Nations General Assembly in its resolution 42/37C of 1987 and reaffirmed by the United Nations Security Council through its resolution 620 (1988). Under this mandate, the Secretary-General is requested

to carry out investigations in response to reports that may be brought to his attention by any Member State concerning the possible use of chemical and bacteriological (biological) or toxin weapons that may constitute a violation of the Geneva Protocol or other relevant rules of customary international law in order to ascertain the facts of the matter and to report promptly the results of any such investigations to all Member States.

Investigations of alleged use will be conducted according to technical guidelines and procedures 
(A/44/561 Annex I) which were endorsed by the General Assembly in 1990. The appendices to the technical guidelines and procedures were updated in 2007.

27. Security Council Resolution 1540 (2004) [15]. In 2004, the Security Council decided that all States shall refrain from providing any form of support to non-State actors who attempt to develop, acquire, manufacture, possess, transport, transfer or use nuclear, chemical or biological weapons and their means of delivery, and requires all States to adopt and enforce appropriate effective laws to this effect. The resolution also requires all States to establish various types of domestic controls to prevent the proliferation of such weapons and their related materials. A Security Council Committee was established pursuant to resolution 1540 to report to the Council on the implementation of the resolution. Security Council resolution 1977 (2011) extended the mandate of the Committee until 25 April 2021.

28. The 1540 Committee has prepared matrices for 179 of the Member States of the United Nations which following approval by the Committee in November and December 2010 are available at http://www.un.org/sc/1540/1540matrix.shtml. This in $O P 2$ - Biological Weapons $(B W)$ requests States to answer the question:

Does national legislation exist which prohibits persons or entities to engage in one of the following activities? Can violators be penalized?

in regard to some 14 activities:

$$
\begin{aligned}
& 1 \text { manufacture/produce } \\
& 2 \text { acquire } \\
& 3 \text { possess } \\
& 4 \text { stockpile/store } \\
& 5 \text { develop } \\
& 6 \text { transport } \\
& 7 \text { transfer } \\
& 8 \text { use } \\
& 9 \text { participate as an accomplice in above-men- } \\
& \text { tioned activities } \\
& 10 \text { assist in above-mentioned activities } \\
& 11 \text { finance above-mentioned activities } \\
& 12 \text { above-mentioned. activities related to means } \\
& \text { of delivery } \\
& 13 \text { involvement of non-State actors in above- } \\
& \text { mentioned. activities } \\
& 14 \text { other }
\end{aligned}
$$

29. In addition, the matrix in $O P 3$ (a) and (b) - Account for/Secure/Physically protect BW including Related Materials requests States to answer the question:
Are any of the following measures, procedures or legislation in place to account for, secure or otherwise protect $B W$ and Related Materials? Can violators be penalized?

in regard to some 17 categories:

1 Measures to account for production

2 Measures to account for use

3 Measures to account for storage

4 Measures to account for transport

5 Other measures for accounting

6 Measures to secure production

7 Measures to secure use

8 Measures to secure storage

9 Measures to secure transport

10 Other measures for securing

11 Regulations for physical protection of facilities/materials/transports

12 Licensing/registration of facilities/persons handling biological materials

13 Reliability check of personnel

14 Measures to account for/secure/ physically protect means of delivery

15 Regulations for genetic engineering work

16 Other legislation/ regulations related to safety and security of biological materials

17 Other

30. The matrix in $O P 3(c)$ and (d) and related matters from $O P 6$ and $O P 10$ - Controls of $B W$ including Related Materials requests States to answer the question:

Which of the following legislation, procedures, measures, agencies exist to control border crossings, export/import and other transfers of $B W$ and Related Materials? Can violators be penalized?

in regard to some 26 categories:

1 Border control

2 Technical support of border control measures

3 Control of brokering, trading in, negotiating, otherwise assisting in sale of goods and technology

4 Enforcement agencies/authorities

5 Export control legislation in place

6 Licensing provisions

7 Individual licensing

8 General licensing

9 Exceptions from licensing

10 Licensing of deemed export/visa

11 National licensing authority

12 Interagency review for licenses

13 Control lists

14 Updating of lists

15 Inclusion of technologies

16 Inclusion of means of delivery 


\author{
17 End-user controls \\ 18 Catch-all clause \\ 19 Intangible transfers \\ 20 Transit control \\ 21 Trans-shipment control \\ 22 Re-export control \\ 23 Control of providing funds \\ 24 Control of providing transport services \\ 25 Control of importation \\ 26 Extraterritorial applicability \\ 27 Other
}

These matrices provide a valuable resource that can be drawn upon by the States Parties to the BTWC in promoting the implementation of Article IV of the Convention.

31. The completed matrices for Ukraine are available at:

http://www.un.org/en/sc/1540/docs/matrices/

Ukraine revised matrix.pdf

and provide detailed information on the legislation and procedures that apply in Ukraine in regard to activities relating to biological weapons as well as to chemical and nuclear weapons.

32. European Union Public Health Preparedness for Cross-Border Health Threats [16]. On 8 December 2011 the European Commission adopted a legislative proposal on the means to address serious cross-border health threats. This proposal is to extend the existing co-ordination mechanism for communicable diseases to all heath threats caused by biological, chemical or environmental causes. It provides for the assessment of risks and the co-ordination of measures from communicable diseases to be extended to all heath threats caused by biological, chemical or environmental causes.

33. United Nations Interregional Crime and Justice Research Institute (UNICRI) CBRN Risk Mitigation and Security Governance Programme [17]. This was launched in 2004, in conjunction with the IAEA, the OPCW, the ISU of the BTWC, the WHO, INTERPOL and the World Customs Organization (WCO), to support the development of an integrated CBRN approach that incorporates all international, regional and national CBRN components into a common strategy. This entails the application of a holistic approach through which all stakeholders, while operating autonomously, can establish common goals, identify and manage resources to achieve these goals, clearly allocate responsibilities and tasks, elaborate functioning channels of communication, create a security culture based on common learning, and ensure that lessons learnt are incorporated and absorbed throughout the whole system.
34. A closely associated element of this programme is to establish regional CBRN Centres of Excellence [18]. Such centres are seen as a cornerstone of these activities by offering a coherent and comprehensive approach covering legal, regulatory, enforcement and technical issues. It is evident that a number of projects will involve Ukraine including one launched in January 2013 entitled Knowledge development and transfer of best practice on bio-safety, bio-security, bio-risk management.

\section{Conclusions}

35. This paper has sought to give an indication of the breadth of activities that scientists need to be aware of if they are to be effective in providing advice to the policy makers and the diplomats in Government. It needs to be recognised that the policy makers and diplomats engaged in a particular activity such as the Biological and Toxin Weapons Convention (BTWC) may well not be involved in some of the other relevant activities and thus be unaware of relevant developments in these other activities. The value that qualified and knowledgeable scientists can bring is thus considerable as they are able to analyse the situation across the range of relevant activities and can use their knowledge to make soundly based proposals that will frequently be acceptable to their fellow scientists in other delegations.

36. For the qualified and knowledgeable scientists to be effective it is vital that the scientist providing scientific advice is able to analyse and summarise the relevant scientific aspects of the particular topic on which advice is to be given to the policy makers and diplomats. Such analysis has to be able to identify the key elements that are relevant and these need to be expressed so that the implications in regard to the various elements of the Convention are clearly appreciated and understood by the policy makers and diplomats. In other words, the relevant scientific aspects have to be analysed, summarized and presented in the context of the Convention together with proposals as to what steps should be taken by the policy makers and diplomats.

37. These qualified and knowledgeable scientists also have a continuing responsibility once they have successfully explained the context of the relevant scientific aspects to the policy makers and diplomats to then follow through by encouraging the national policy makers to take appropriate action nationally to implement the changes that would enhance the effectiveness nationally of the implementation of the BTWC.

38. Qualified and knowledgeable scientists who are effective in providing advice to the pol- 
icy makers and diplomats have an additional bonus - in that they are well qualified to assist in raising awareness and facilitating outreach to all those engaged in the life sciences about the issues and the progress being made by the States Parties in strengthening the effectiveness of the Biological and Toxin Weapons Convention and thereby helping to make it a safer world for all of us.

\section{Postscript}

39. I have chosen to write this article on The Vital Importance of Providing Sound Scientific Advice to Policy Makers in Government in recognition of the outstanding contributions that Ambassador Professor Dr. Serhiy Vasilyovich Komisarenko has made as a member of the delegation of Ukraine, which he has frequently led, to the meetings of the States Parties to the Biological and Toxin Weapons Convention in Geneva over the past eight years.

\section{References}

1. Convention on the Prohibition of the Development, Production and Stockpiling of Bacteriological (Biological) and Toxin Weapons and on Their Destruction, available at http:// www.opbw.org/ and at http://www.unog. ch/80256EE600585943/(httpPages)/04FBBDD 6315AC720C1257180004B1B2F?OpenDocument

2. United Nations, The Seventh Review Conference of the States Parties to the Convention on the Prohibition of the Development, Production and Stockpiling of Bacteriological (Biological) and Toxin Weapons and on their Destruction, Geneva, 5 - 22 December 2011, Final Document, BWC/CONF.VII/7, 13 January 2012. Available at http://unog.ch/bwc and at http://www.opbw. org

3. See http://www.who.int/ihr/biosafety/publications_WHO_CDS_EPR_2006_6/en/
4. See http://www.oie.int/our-scientific-expertise/ biological-threat-reduction/

5. See http://www.fao.org/wsfs/en/

6. See http://www.cbd.int/convention

7. See http://bch.cbd.int/protocol/

8. See http://www.unep.org/biosafety/

9. Available at http://www.unep.org/biosafety/ National\%20Biosafety\%20frameworks.aspx

10. See http://www.opcw.org/chemical-weaponsconvention/

11. See http://www.un.org/disarmament/WMD/ Bio/1925GenevaProtocol.shtml

12. United Nations, The Seventh Review Conference of the States Parties to the Convention on the Prohibition of the Development, Production and Stockpiling of Bacteriological (Biological) and Toxin Weapons and on their Destruction, Geneva, 5 - 22 December 2011, Final Document, BWC/CONF.VII/7, 13 January 2012. Available at http://unog.ch/bwc and at http://www.opbw. org

13. See http://www.un.org/disarmament/WMD/ Secretary-General_Mechanism/

14. United Nations, The Seventh Review Conference of the States Parties to the Convention on the Prohibition of the Development, Production and Stockpiling of Bacteriological (Biological) and Toxin Weapons and on their Destruction, Geneva, 5 - 22 December 2011, Final Document, BWC/CONF.VII/7, 13 January 2012. Available at http://unog.ch/bwc and at http://www.opbw. org

15. See http://www.un.org/en/sc/1540/

16. See http://ec.europa.eu/health/preparedness_ response/policy/hsi/index_en.htm

17. See http://www.unicri.it/topics/cbrn/

18. See http://www.unicri.it/topics/cbrn/coe/ and http://www.cbrn-coe.eu/ 